\title{
IN VITRO EVALUATION OF ANTICANCER POTENTIAL OF ERYTHRINA VARIEGATA L. ON BREAST CANCER CELL LINES
}

\author{
VAISHALI RAI M ${ }^{1}$, VINITHA RAMANATH PAI ${ }^{1 *}$, SAMUEL KEVIN ${ }^{1}$, HERGA P KEDILAYA ${ }^{2}$ \\ ${ }^{1}$ Department of Biochemistry, Yenepoya Medical College, Yenepoya University, Mangalore, Karnataka, India. ${ }^{2}$ Department of Biochemistry, \\ Srinivas Institute of Medical Sciences and Research Centre, Mangalore, Karnataka, India. Email: vinitharpai@gmail.com
}

Received: 13 March 2017, Revised and Accepted: 15 April 2017

\section{ABSTRACT}

Objective: Species of Erythrina variegata L. is reported to be used in the treatment of cancer in traditional/folklore medicine which could be explored for their anticancer potential. We aimed to evaluate the anticancer activity of crude extracts of the leaves of $E$. variegata with two solvents; explore the mechanism of cytotoxicity with the effective extract and correlation with the phytochemicals in the extract.

Methods: The extracts with Erythrina variegata L methanol (EVM) and chloroform (EVC) as solvents were screened for cytotoxicity by 3-(4,5-dimethylthiazol-2-yl)-2,5-diphenyltetrazolium assay on MDA-MB-231 and MCF-7 cell lines. The effective extract was further evaluated on MDA-MB-231 cells by nucleoprotein content estimation, and cell morphology was studied. High resolution liquid chromatography mass spectrometry (HRLCMS) of EVM was done to find the phytochemical composition.

Results: Among the two extracts, EVM was effective at an inhibitory concentration ( $\mathrm{IC}_{50}$ ) value of $92 \mu \mathrm{g} / \mathrm{ml}$ and $143 \mu \mathrm{g} / \mathrm{ml}$ on MCF-7 and MDA-MB-231 cells, respectively. At the $\mathrm{IC}_{50}$ value $(143 \mu \mathrm{g} / \mathrm{ml})$ the nucleoprotein content of the cells was $58.2 \%$, and the apoptotic index was calculated to be 51.8\%. EVM treated group showed significant morphological changes suggestive of apoptosis. HRLCMS revealed the presence of rutin, podocarpatriene, and cepharanthine which are known to be cytotoxic.

Conclusion: This report is a contribution toward the validation of E. variegata as a potential source of anticancer agents

Keywords: Erythrina variegata, Cytotoxicity, Apoptosis, MDA-MB-231, Podocarpatriene.

(C) 2017 The Authors. Published by Innovare Academic Sciences Pvt Ltd. This is an open access article under the CC BY license (http://creativecommons. org/licenses/by/4. 0/) DOI: http://dx.doi.org/10.22159/ajpcr.2017.v10i7.18409

\section{INTRODUCTION}

Cancer is a common cause for mortality, standing second after cardiovascular disorders, and an over looming threat to mankind [1,2]. In developing countries like India, breast cancer is highly prevalent and in years to come the numbers may increase alarmingly due to environmental pollution, changes in lifestyle and inclusion of genetically modified food in the diet [3]. The histology of breast cancer shows a heterogeneous population of cells and like any cancer, the development is regulated by a large number of genes as well [4,5]. Therefore compounds that arrest the cell cycle, suppress cell proliferation, induce cell death and/or activate apoptosis would be ideal for the treatment of cancer [6-11].

Plants are an important source of therapy for human ailments. Worldwide and more so in India, there are a number of tribal/ethnic groups who have a vast knowledge of the use of plants in therapy. The "ethnomedicinal studies" of the therapeutic values of these plants involve a systematic scientific evaluation [12]. A number of ethnomedicinal species have been identified in families' such as Apiaceae, Brassicaceae, Fabaceae, Rutaceae, and Zingiberaceae for the treatment of cancer [13]. In particular, family Fabaceae contains species such as Phaseolus vulgaris L., Glycine max L., Vigna unguiculata, Cajanus cajan (L.) Millsp. (Pigeon pea), and Arachis hypogaea which have exhibited cytotoxic effects on tumor/cancer cells [13]. The anticancer properties of members of Fabaceae have been traced to the presence of phytochemicals such as isoflavones genistein, anthocyanins, $\beta$-sitosterol, and resveratrol.

Erythrina variegata L. (Family, Fabaceae) also known as a coral tree is a medicinal plant that is widely distributed in the tropical and subtropical regions of the world. The plant has a wide range of properties one of them being cytotoxicity [14]. The leaves and roots from this plant are reported to be used in the Chinese herbal medicine for treatment of cancer [15]. Erythrina species have also been reported to be used in folk medicine against stomach cancer [16]. Although the plant is being used in alternative medicines for cancer, very few investigations have evaluated the mechanism of action. The chloroform and carbon tetrachloride partitionates of the methanolic extract of the bark of E. variegata L (EVM). are shown to be cytotoxic [17]. The phytochemical analysis of the Soxhlet methanol extracts of the bark has also exhibited cytotoxicity [18]. In this study, crude extracts of the leaf powder of E. variegata L., in two solvents, prepared by a very simple extraction procedure, have been screened for their cytotoxic efficacy and the more effective of the two extracts has been studied further for evaluation of the mechanism of cell death and correlation with the phytochemicals in the extract.

\section{METHODS}

\section{Plant material}

The leaves of E. variegata were collected from Mangalore, Karnataka, Dakshina Kannada district of Karnataka, India, and were identified and authenticated by Dr. Noeline J. Pinto, Taxonomist, St. Agnes College, Mangalore, Karnataka, India. A voucher specimen (SAC/BOT-15/104) was submitted at the herbarium for future reference.

\section{Preparation of extracts}

Leaves of E. variegata L. were collected, washed with distilled water, shade dried and cut into small pieces. These dried samples were powdered using a mixer grinder. Extracts $(10 \% \mathrm{w} / \mathrm{v})$ were made at room temperature, using two solvents, i.e., methanol and chloroform with intermittent shaking for $24 \mathrm{hrs}$. The extracts were filtered through Whatman no. 1 and the clear filtrate was evaporated to dryness to form 
methanol soluble (EVM) and chloroform soluble (EVC) extracts and stored at $4^{\circ} \mathrm{C}$ until further use.

\section{Cell lines}

MCF-7 michigan cancer foundation-7; non-metastatic origin and MDA-MB-231 (MD Anderson Series); metastatic origin procured from National Centre for Cell Sciences, Pune, India, were cultured in Dulbecco's Modified Eagle Medium supplemented with, 10\% heat-inactivated fetal bovine serum, $2 \mathrm{mM}$ L-glutamine, penicillin $(100 \mathrm{IU} / \mathrm{ml})$, streptomycin $(100 \mu \mathrm{g} / \mathrm{ml})$, and amphotericin-B $(5 \mu \mathrm{g} / \mathrm{ml})$ in humidified atmosphere of $5 \% \mathrm{CO}_{2}$ at $37^{\circ} \mathrm{C}$. The cells were trypsinized with $0.25 \%$ trypsin-ethylenediaminetetraacetic acid solution. The stock cultures were grown in $25 \mathrm{~cm}^{2}$ flat bottles, and the cell viability studies were conducted in 96 well microtiter plates.

\section{Cytotoxicity by 3-(4,5-dimethylthiazol-2-yl)-2,5-diphenyltetrazo lium (MTT) assay}

Cells were seeded in 96 well flat bottom microtiter plates at a density of $5 \times 10^{4}$ cells per well for MTT assay $[19,20]$ and were cultured at $37^{\circ} \mathrm{C}$, in $5 \% \mathrm{CO}_{2}$ atmosphere, for $24 \mathrm{hrs}$, to allow cell adhesion. After $24 \mathrm{hrs}$, when partial monolayers were formed, cells were treated with different concentrations of either the standard drug (doxorubicin/cisplatin) $(0.62 \mu \mathrm{g} / \mathrm{ml}, 1.25 \mu \mathrm{g} / \mathrm{ml}, 2.5 \mu \mathrm{g} / \mathrm{ml}, 5 \mu \mathrm{g} / \mathrm{ml}$, and $10 \mu \mathrm{g} / \mathrm{ml})$ or the extracts $(31.25 \mu \mathrm{g} / \mathrm{ml}, 62.5 \mu \mathrm{g} / \mathrm{ml}, 125 \mu \mathrm{g} / \mathrm{ml}, 250 \mu \mathrm{g} / \mathrm{ml}$, and $500 \mu \mathrm{g} / \mathrm{ml}$ ) and further incubated for $48 \mathrm{hrs}$. Post-treatment, $100 \mu \mathrm{l}$ of freshly prepared MTT $(1 \mathrm{mg} / \mathrm{ml}$ phosphate buffered saline [PBS]) was added to each well. The plates were shaken gently and incubated at $37^{\circ} \mathrm{C}$ in $5 \% \mathrm{CO}_{2}$ atmosphere for $4 \mathrm{hrs}$. After $4 \mathrm{hrs}$, the supernatant was removed, and the formazan crystals formed in the cells were solubilized by addition of $100 \mu \mathrm{l}$ of dimethyl sulfoxide. The absorbance was read using a microplate reader (Bio-Tek, ELX-800 MS) at $570 \mathrm{~nm}$. The assay was done in triplicate for each of the extracts.

The percentage growth inhibition was calculated using the formula below:

$\%$ growth inhibition $=[($ control absorbance - test absorbance $) /($ control absorbance)] $\times 100$

A graph was plotted with concentration of standard drug/extract on $\mathrm{x}$-axis and absorbance on the y-axis. From this curve, inhibitory concentration $\left(\mathrm{IC}_{50}\right)$ (concentration of drug required to kill $50 \%$ of cells in exponentially growing cultures after a $48 \mathrm{hrs}$ exposure to the drug) values were calculated. The most effective extract was used for further studies with MDA-MB-231 cell line.

\section{Nucleoprotein content assay with MDA-MB-231}

The assay was performed as the procedure given by Gillies et al., 1986 [21]. Cells were seeded in 96 well flat bottom microtiter plates at a density of $1 \times 10^{5}$ cells per well and were cultured at $37^{\circ}{ }^{\circ} \mathrm{C}$, in $5 \% \mathrm{CO}_{2}$ atmosphere, for $24 \mathrm{hrs}$, to allow cell adhesion. MDA-MB-231 cells were treated with varying concentrations of either the standard drug (cisplatin) $(0.5 \mu \mathrm{g} / \mathrm{ml}$, $1.0 \mu \mathrm{g} / \mathrm{ml}$, and $2 \mu \mathrm{g} / \mathrm{ml})$ or the extracts $(12.5 \mu \mathrm{g} / \mathrm{ml}, 25 \mu \mathrm{g} / \mathrm{ml}, 50 \mu \mathrm{g} / \mathrm{ml}$, $100 \mu \mathrm{g} / \mathrm{ml}$, and $200 \mu \mathrm{g} / \mathrm{ml}$ ) for $48 \mathrm{hrs}$. After the treatment, the medium was aspirated, and the cells were washed with PBS. The cells were then fixed in $4 \%$ formaldehyde for 30 minutes. The nucleoprotein content of the fixed cells was stained with crystal violet $(0.1 \%)$ for 60 minutes and then destained by multiple washes with distilled water. The plates were left overnight for air drying. Remaining crystal violet was solubilized in $100 x$ dilution of glacial acetic acid $(0.1 \mathrm{ml})$. Absorbance was measured at $590 \mathrm{~nm}$ and read using a microplate reader (BMG Labtech, Fluostar Omega V3.00R2). The nucleoprotein content was calculated as follows:

$\%$ nucleoprotein content $=[($ control absorbance - test absorbance $) /$ control absorbance) $] \times 100$.

\section{Morphological detection of apoptosis}

Morphological detection of apoptosis was studied using acridine orange and Giemsa stains as described earlier [22]. Cells were seeded in a 6 well microtiter plate at a density of $5 \times 10^{5}$ cells per well and cultured at $37^{\circ} \mathrm{C}$, in $5 \% \mathrm{CO}_{2}$ atmosphere, for $24 \mathrm{hrs}$. After $24 \mathrm{hrs}$, medium was removed, and cells were exposed to different concentrations of the standard drug (cisplatin: $0.5 \mu \mathrm{g} / \mathrm{ml}$ ) and the crude extracts $(50 \mu \mathrm{g} / \mathrm{ml}, 150 \mu \mathrm{g} / \mathrm{ml}$, and $250 \mu \mathrm{g} / \mathrm{ml}$ ) for $48 \mathrm{hrs}$. Post-treatment, the cells were collected, washed and suspended in PBS (pH 7.4). $100 \mu$ of the cell suspension was used for acridine orange staining $(1 \mathrm{mg} / \mathrm{ml})$. After staining, the cells were observed for morphological features of apoptosis under a fluorescent microscope (Olympus CX41) and photographed. Viable cells stain green, early apoptotic cells stain yellow and late apoptotic cells appear reddish orange. 200 cells were counted for each data point, and the apoptotic index was calculated as [number of apoptotic cells/total cells counted] $\times 100$.

For Giemsa staining: Cells were treated with diluted Giemsa (1 in $20 \mathrm{ml}$ Sorenson's buffer) after fixation (methanol:acetic acid) and were observed under a light microscope for morphological features of apoptosis such as membrane blebbing, nuclear fragmentation, chromatin condensation, and apoptotic bodies.

\section{Qualitative screening for phytochemicals}

The phytochemical analysis was performed with the EVM. Qualitative analysis was peformed to detect the presence/absence of phytochemicals such as alkaloids by Wagner's test and Hager's test; flavonoids by alkaline reagent test and lead acetate test; tannins and phenols by ferric chloride test and gelatin test; saponins by foam test; carbohydrates by Molisch's test and Benedict's test; amino acids by ninhydrin test and proteins by biuret test, glycosides by Keller-Killiani test, and bromine water test; steroids and terpenoids by Salkowski's test and Liebermann Burchard's test, according to the standard procedures [23].

\section{Quantitative analysis of phytochemicals}

Quantitative analysis of the EVM. was performed according to the standard procedures [23]. The total flavonoid content was determined by aluminum chloride colorimetric technique. Steroids were estimated by Liebermann-Burchard's reaction method. Alkaloids, tannins, and saponins were estimated according to the standard procedures [23]. The samples were analyzed in triplicates $(n=3)$, and the results were expressed as mean \pm standard deviation (SD) values.

High resolution liquid chromatograph mass spectrometer (HRLCMS) analysis

HRLCMS of the EVM was done using a quadrupole time-of-flight (TOF/Q-TOF) mass spectrometer (Agilent Technologies, USA) at Indian Institute of Technology, Bombay. Mass spectrometer was carried out in positive and negative ionization mode with a mass/charge ratio ranging from 50 to $1000.2 \mu \mathrm{l}$ of the sample was used for the analysis. Elution was done using a solvent gradient of acetonitrile:water $(80: 20 \mathrm{v} / \mathrm{v})$ with a flow rate of $0.3 \mathrm{ml} /$ minutes for 30 minutes.

\section{Statistical analysis}

Data were expressed as mean \pm SD values of triplicate experiments $(n=3)$. Analysis was performed using one-way ANOVA followed by least significant difference post hoc test for comparison between control and treatment groups. Comparisons of the number of viable and apoptotic cells, in the various treated and untreated groups were done by Chi-square analysis using SPSS version 14 software (IBM). $p<0.05$ was considered to be statistically significant.

\section{RESULTS AND DISCUSSION}

This study is an attempt to assess the cytotoxic effects of the leaf extracts of E. variegata and associate the activity with the phytochemical composition of the extract as well as validate its use in the traditional medicine [16]. Among the extracts prepared from two solvents, i.e., methanol and chloroform, the extractive yield of $E$. variegata leaves was maximum in methanol $(13.3 \% \mathrm{w} / \mathrm{w})$ followed by chloroform $(5.2 \% \mathrm{w} / \mathrm{w})$. In the preliminary screening, the crude EVM leaves obtained by cold maceration method showed significant cytotoxicity 
with IC ${ }_{50}$ values of $92 \pm 1.8 \mu \mathrm{g} / \mathrm{ml}$ and $143.0 \pm 3.4 \mu \mathrm{g} / \mathrm{ml}$ for MCF-7 and MDA-MB-231 cells, respectively. However, the chloroform soluble extracts did not show effective cytotoxicity against MDA-MB-231 (IC value: $365.0 \pm 2.5 \mu \mathrm{g} / \mathrm{ml}$ ) and MCF-7 cells ( $\left.\mathrm{IC}_{50}>500 \mu \mathrm{g} / \mathrm{ml}\right)$. Cisplatin and doxorubicin (positive controls) gave an $\mathrm{IC}_{50}$ value of $0.5 \pm 0.13 \mu \mathrm{g} / \mathrm{ml}$ and $1.09 \pm 0.03 \mu \mathrm{g} / \mathrm{ml}$ against MDA-MB-231 and MCF-7 cells, respectively, by MTT assay (Fig. 1). Statistical analysis, shows that the cytotoxicity of the EVM was significant $(\mathrm{p}<0.001)$ than chloroform soluble extracts on both the cell lines (Table 1). Unlike an earlier report involving sensitivity of genistein $(10 \mu \mathrm{M})$, an isoflavonoid molecule, on six different breast cancer cell lines, which has shown differences in the sensitivity of genistein between cell lines. In this study there were small differences in the $\mathrm{IC}_{50}$ values of the EVM between the two breast cancer cell lines ( $>0.05$ ) (Table 1). This may be suggestive of a common mechanism of growth modulation by the extract in both the cell lines which are genetically/phenotypically different [24]. Hence, further studies for the mechanism for cytotoxicity were conducted on MDA-MB-231 cells, which are triple receptor negative cells, with methanol soluble (EVM) extracts.

The earlier reports from the in vitro studies of extracts of the stem bark of E. variegata were also with methanol as solvent by Soxhlet extraction in which the phytochemical was purified and identified to be erystagallin A, molecule of isoflavonoid nature, that had an $\mathrm{IC}_{50}$ value of $3.3 \mu \mathrm{g} / \mathrm{ml}$ against T47D breast cancer cell line [25]. Yet another report of an in vivo study using methanol extract of the root bark of E. variegata has shown decrease in the numbers of cancer cells, packed cell volume and increase in tumor weight and survival time of the animals, clearly indicating the presence of the anticancer activity of the methanol extracts of the root bark as well [15]. The study has not speculated on the phytochemical responsible for the cytotoxic effect, and there was a difference in the procedure for extract preparation which involved successive extraction with petroleum ether and methanol. The dichloromethane: methanol soluble whole plant extract of Erythrina lysistemon, another species from the same genus, has shown cytotoxicity with $15 \%$ growth inhibition and the anticancer effect was attributed to the presence of phytochemicals [26]

The cytotoxicity of the drug can be measured in terms of cell viability, nucleoprotein content, cell proliferation, cell cycle analysis, etc. [27]. A decrease in the nucleoprotein content clearly suggests extract/drug induced cell detachment/decreased cell proliferation. EVM appear to show a dose dependent decrease in live cells as shown in the nucleoprotein content. At the $\mathrm{IC}_{50}$ values derived from MTT assay $(143 \mu \mathrm{g} / \mathrm{ml})$ the survival rate of the cells was $58.2 \%$, while at a higher dose $(200 \mu \mathrm{g} / \mathrm{ml})$ of the extract, the viability of the cells decreased. Cisplatin, the positive control has also shown a similar dose-dependent decrease in nucleoprotein content (Fig. 2). A similar effect was seen by the action of docetaxel, anticancer drug, on MDA-MB-231 cells, and the mechanism of action was apoptosis [27]

Staining with acridine orange (Fig. 3) showed the presence of viable cells with green fluorescence, early apoptotic cells was yellow in color and late apoptotic cells appeared reddish orange. In the treatment groups, significant morphological changes such as cell shrinkage and

Table 1: $\mathrm{IC}_{50}$ values of control and crude extracts of $E$. variegata against MCF-7 and MDA-MB-231 cells

\begin{tabular}{lll}
\hline Control/crude extract & $\mathbf{I C}_{\mathbf{5 0}}(\boldsymbol{\mu g} / \mathbf{m l})$ & \\
\cline { 2 - 3 } & MDA-MB-231 & MCF-7 \\
\hline Doxorubicin & - & $1.09 \pm 0.03$ \\
Cisplatin & $0.5 \pm 0.1$ & - \\
Methanol extract (EVM) & $143.0 \pm 3.4^{*}$ & $92 \pm 1.8^{*}$ \\
Chloroform extract (EVC) & $365.0 \pm 2.5$ & $>500$ \\
\hline
\end{tabular}

The $\mathrm{IC}_{50}$ values were determined from the cell viability curve at $50 \%$ after $48 \mathrm{hrs}$ of treatment and expressed as $\mu \mathrm{g} / \mathrm{ml}$. Data are represented as mean $\pm \mathrm{SD}(\mathrm{n}=3)$; *statistical significance $\mathrm{p}<0.001$ between control versus treatment groups, E. variegata: Erythrina variegata, $\mathrm{IC}_{50}$ : Inhibitory concentration

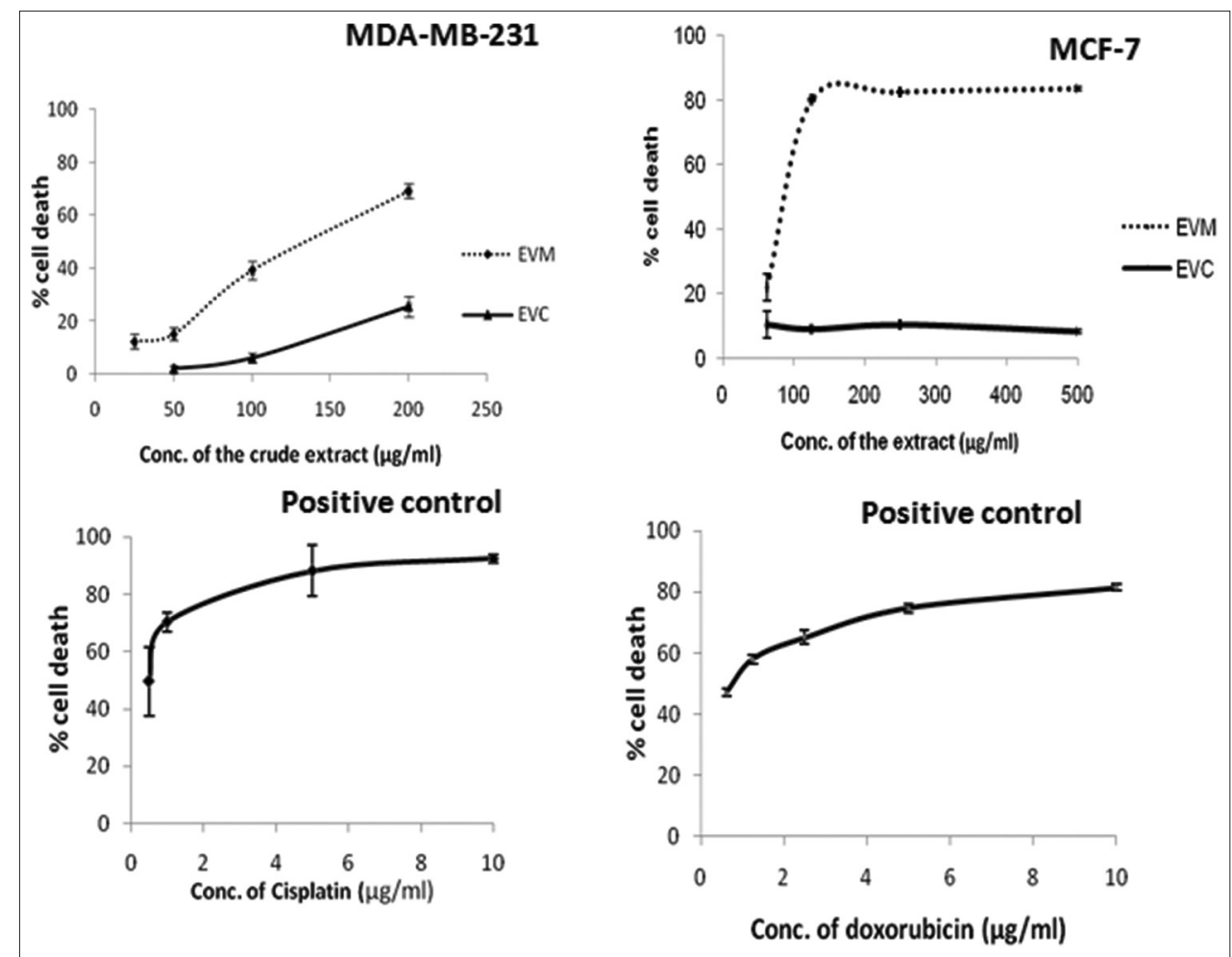

Fig. 1: Effect of Erythrina variegata methanol and chloroform crude extracts on MDA-MB-231 and MCF-7 cells by MTT assay with cisplatin and doxorubicin (positive control). Methanol soluble extract (EVM), chloroform soluble extract (EVC). The inhibitory concentration values determined from the graph at $50 \%$ cell death after $48 \mathrm{hrs}$ of treatment 


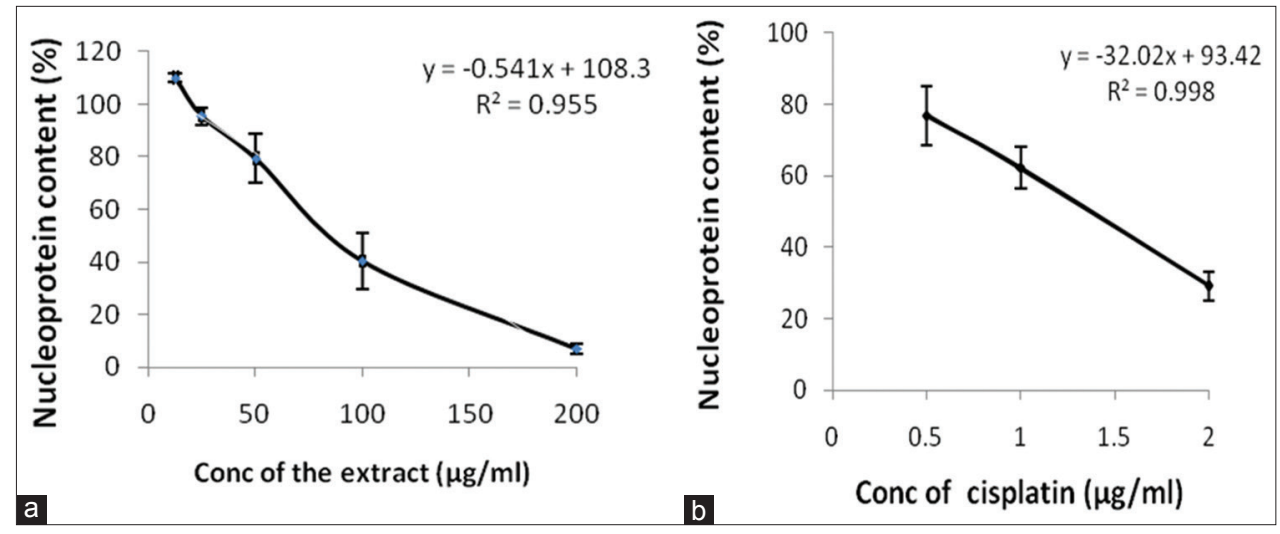

Fig. 2: Effect of varying concentrations of (a) methanol soluble crude leaf extract of E. variegata (EVM) and (b) positive control (cisplatin) on nucleoprotein content of MDA-MB-231 cells. Values are mean \pm SD $(n=3)$
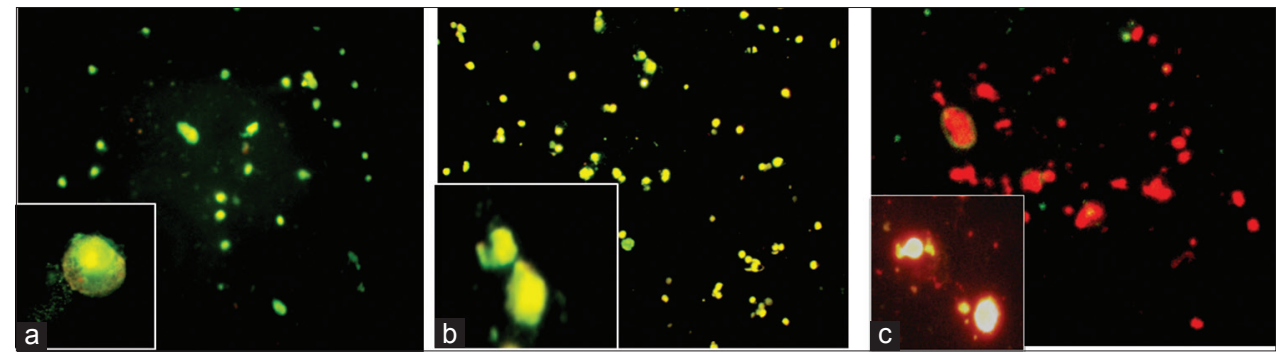

Fig. 3: Microphotography of MDA-MB-231 cells stained with acridine orange (a) viable cells (b) early apoptotic cells (c) late apoptotic cells (magnification of the picture - 20x and inset 40x)
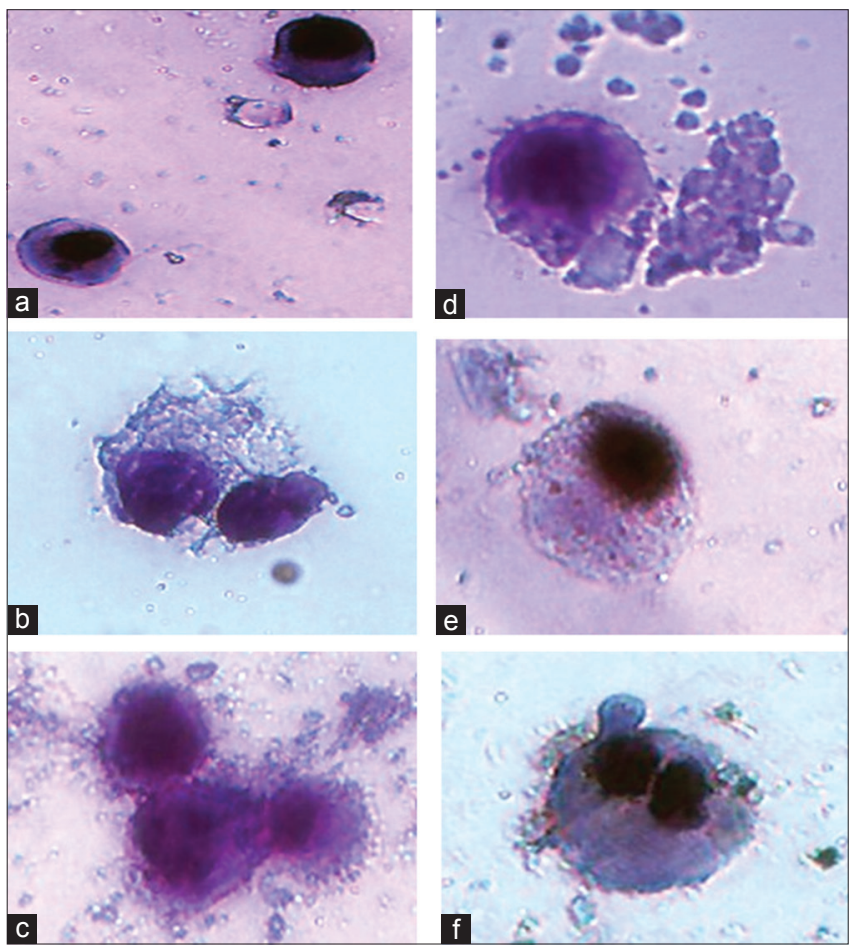

Fig. 4: Microphotography (magnification: 40x) of MDA-MB-231 cells stained with Giemsa (a) viable cells,

(b) membrane disruption, (c and f) membrane blebbing,

(d) apoptotic bodies, (b and e) chromatin condensation,

(f) fragmented nuclei

reduced cell density were observed compared to the normal cells that stained green with large and clear intact nucleus (Fig. 3).
Table 2: Concentration of the phytochemicals $(\% \mathrm{w} / \mathrm{w})$ in the methanol soluble leaf extracts of $E$. variegata $\mathrm{L}$.

\begin{tabular}{ll}
\hline Phytoconstituents & $\begin{array}{l}\text { Concentration of the } \\
\text { phytochemicals }(\% \mathbf{w} / \mathbf{w})\end{array}$ \\
\hline Flavonoids & $92.6 \pm 2.4$ \\
Tannins & $18.7 \pm 4.5$ \\
Steroids & $15.3 \pm 1.2$ \\
Saponins & $14.2 \pm 0.1$ \\
Alkaloids & $2.7 \pm 0.8$ \\
\hline
\end{tabular}

E. variegata: Erythrina variegata

When stained with Giemsa (Fig. 4), characteristic markers of apoptosis such as chromatin condensation, membrane-bound apoptotic bodies, fragmented nuclei, plasma membrane blebbing, membrane disruption were observed. These results suggest that the mechanism of action in cells treated with EVM was apoptosis.

There was an increase in the percentage of apoptotic cells with the increase in concentrations of the extract (Fig. 5). The calculated apoptotic index in the extract treated groups was $32 \%$ at $50 \mu \mathrm{g} / \mathrm{ml}$, $56 \%$ at $150 \mu \mathrm{g} / \mathrm{ml}$, and $82 \%$ at $250 \mu \mathrm{g} / \mathrm{ml}$ of EVM. In the cisplatin treated group, the apoptotic index was found to be $80 \%$ at an $\mathrm{IC}_{50}$ value $(0.5 \mu \mathrm{g} / \mathrm{ml})$. Apoptotic index at an IC ${ }_{50}$ value of $143 \mu \mathrm{g} / \mathrm{ml}$ was calculated from the curve plotted with concentration of EVM on the X axis and apoptotic index on the $\mathrm{Y}$ axis and was found to be $51.8 \%$. Apoptotic index of treated cells was significantly different from untreated cells $(p<0.001)$. Chemotherapeutic agents are known to induce cytotoxicity by apoptosis [28]. Plant extracts have diverse groups of phytochemicals, each having its own mechanism of action with the final outcome being apoptosis $[29,30]$. It has been suggested in earlier reports that since MCF-7 cells are caspase 3 deficient, the cytotoxicity may be due to a caspase 3 independent mechanism, such as activation of other caspases which when activated result in chromatin condensation or cell death in the extract treated cells [9]. 
Table 3: Anticancer components detected in the methanol soluble leaf extracts of $E$. variegata by HRLCMS

\begin{tabular}{llll}
\hline Name of the compound & RT & Molecular formula & Molecular mass \\
\hline Rutin & 20.9 & $\mathrm{C}_{27} \mathrm{H}_{30} \mathrm{O}_{16}$ & 610.15 \\
$3 \alpha$-hydroxy-4,4-bisnor-8,11,13-Podocarpatriene & 0.8 & $\mathrm{C}_{15} \mathrm{H}_{20} \mathrm{O}$ & 216.15 \\
Cepharanthine & 21.5 & $\mathrm{C}_{37} \mathrm{H}_{38} \mathrm{~N}_{2} \mathrm{O}_{6}$ & 606.27 \\
Arachidonoylmorpholine & 8.8 & $\mathrm{C}_{24} \mathrm{H}_{39} \mathrm{NO}_{2}$ & 373.30 \\
\hline
\end{tabular}

E. variegata: Erythrina variegata, HRLCMS: High resolution liquid chromatograph mass spectrometer, HRLCMS conditions: Mobile phase: Acetonitrile: Methanol (gradient elution), detector: UHPLC PDA detector; flow rate: $0.3 \mathrm{ml} /$ minutes; injection volume: $2 \mu \mathrm{l}$; run time: 30 minutes. MS ESI (positive and negative mode ionization, $\mathrm{m} / \mathrm{z}$ from 50 to 1000 )

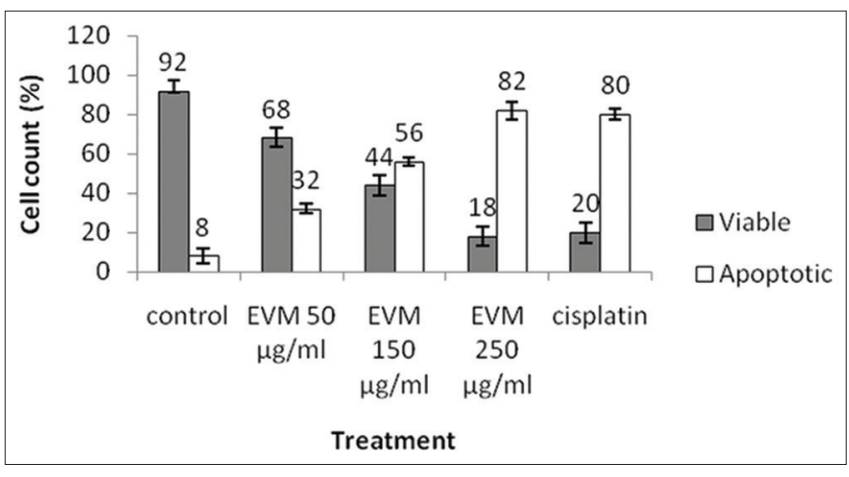

Fig. 5: Comparison of viable and apoptotic MDA-MB-231 cells at varying concentrations of extracts with Erythrina variegata $\mathrm{L}$ methanol for $\mathbf{4 8} \mathrm{hrs}$ with acridine orange staining. Data are expressed as mean $\pm \operatorname{SD}(n=3)$

Preliminary phytochemical screening of the EVM by qualitative tests was positive for flavonoids, alkaloids, tannins, phenols, saponins, carbohydrates, glycosides, steroids and terpenoids, and negative for proteins. The results of the quantitative estimation of the chemical constituents - flavonoids, tannins, steroids, saponins, and alkaloids are summarized in Table 2. The quantitative analysis revealed highest concentrations of flavonoids $(92.57 \pm 2.4 \% \mathrm{w} / \mathrm{w})$, followed by tannins, steroids, saponins, and alkaloids. The role of phytochemicals such as flavonoids, alkaloids, and terpenoids in cancer chemoprevention and chemotherapy has been reported [31]. Flavonoids are known to have cytotoxic effects, and the presence of flavonoids such as rutin has been reported by the HRLCMS data.

The chemical profile of EVM by HRLCMS showed the presence of three compounds with reported cytotoxicity, i.e., Rutin, $3 \alpha$-hydroxy- 4 , 4-bisnor-8, 11, 13-podocarpatriene, and cepharanthine (Table 3). In another study, the methanol extracts of the stem bark of E. variegata have revealed the presence of compounds such as 6-hydroxygenistein, $3 \beta$, 28-dihydroxyolean-12-ene, epilupeol and stigmasterol belonging to the triterpenoids and steroid groups of compounds and exhibiting varying degrees of cytotoxicity [18]. A terpenoid pentacyclic glycoside has been isolated from the leaves of $E$. variegata which has shown to be cytotoxic on breast cancer cell line T47D [25].

Rutin is a glycoside of quercetin. It is shown to have antimutagenic action and is an inhibitor of carcinogenic process and a potential cancer preventive agent. Members of the broad flavonoid family have exhibited a wide variety of anticancer effects acting as antioxidants, angiogenesis inhibition, and potent cytotoxic agents [32]. Podocarpatrienes are cytotoxic diterpenoids that have been reported from Podocarpus madagascariensis, Jatropha species which have been used in the treatment for leukemia [33]. Cepharanthine, a plantderived alkaloid, has proven to have anticancer activity on murine P388 doxorubicin - sensitive (P388/S) and - resistant (P388/DOX) cells. The mechanism of action has been studied to be apoptosis [34].

In conclusion, methanol appears to be a good solvent for extraction of anticancer principle from the leaves of E. variegata. The mechanism of cell death appears to be apoptosis. HRLCMS of the methanol soluble crude extract showed the presence of rutin (phenol), podocarpatriene (terpenoid), cepharanthine (an alkaloid), that are known for cytotoxic activity. This preliminary study validates the traditional use of E. variegata $\mathrm{L}$. in the treatment for cancer.

\section{ACKNOWLEDGMENT}

The study was funded by the Yenepoya University Junior Research Fellowship Program. The authors also acknowledge the Yenepoya Research Centre, Cell Culture Facility, and SAIF, IIT, Bombay, for the HRLCMS analysis.

\section{REFERENCES}

1. Jemal A, Siegel R, Ward E, Murray T, Xu J, Thun MJ. Cancer statistics, 2007. CA Cancer J Clin 2007;57(1):43-66.

2. Bray F, Møller B. Predicting the future burden of cancer. Nat Rev Cancer 2006;6(1):63-74.

3. Sen U, Sankaranarayanan R, Mandal S, Ramanakumar AV, Parkin DM, Siddiqi M. Cancer patterns in eastern India: The first report of the Kolkata cancer registry. Int J Cancer 2002;100(1):86-91.

4. Hedenfalk IA, Ringnér M, Trent JM, Borg A. Gene expression in inherited breast cancer. Adv Cancer Res 2002;84:1-34.

5. Ingrasson $\mathrm{S}$. Breast cancer: Introduction. Semin Cancer Biol 2001;11:323-6.

6. Dobashi Y, Takehana T, Ooi A. Perspectives on cancer therapy: Cell cycle blockers and perturbators. Curr Med Chem 2003;10(23):2549-58.

7. Fan S, Cherney B, Reinhold W, Rucker K, O'Connor PM. Disruption of p53 function in immortalized human cells does not affect survival or apoptosis after taxol or vincristine treatment. Clin Cancer Res 1998;4(4):1047-54.

8. Garrett MD. Cell cycle control and cancer. Curr Sci 2001;81:515-22.

9. Merlin NJ, Parthasarthy V, Santhoshkumar TR. Induction of apoptosis in human breast cancer cell line MCF-7 by phytochemicals from Gmelina asiatica. Afr J Biotechnol 2010;9:4451-6.

10. Sandal T. Molecular aspects of the mammalian cell cycle and cancer. Oncologist 2002;7(1):73-81.

11. Tachibana KE, Gonzalez MA, Coleman N. Cell-cycle-dependent regulation of DNA replication and its relevance to cancer pathology. J Pathol 2005;205:123-9.

12. Jahan R, Hossain S, Seraj S, Nasrin D, Khatun Z, Ranidas P, et al. Centella asiatica (L.) Urb.: Ethnomedicinal uses and their scientific validations. Am Eur J Sustain Agric 2012;6:261-70.

13. Amri E. The role of selected plant families with dietary ethnomedical species used as anticancer. J Med Plants Stud 2014;2:28-39.

14. Nkengfack AE, Azebaze AG, Waffo AK, Fomum ZT, Meyer M, van Heerden FR. Cytotoxic isoflavones from Erythrina indica. Phytochemistry 2001;58(7):1113-20.

15. Baskar N, Parimaladevi B, Mohankumar R. Evaluation of anticancer activity of methanol extract of root bark of Erythrina variegata Linn. J Pharm Res 2010;3:1724-5.

16. Hartwell JL. Plants used against cancer. A survey. Lloydia 1970;33(4):288-392.

17. Rahman MZ, Sultana SJ, Faruquee CF, Ferdous F, Rahman MS, Islam MS, et al. Phytochemical and biological investigations of Erythrina variegata. Saudi Pharm J 2007;15:140-5.

18. Suryawanshi HP, Patel MR. Traditional uses, medicinal and phytopharmacological properties of $E$. Indica Lam: An overview. Int J Res Ayurveda Pharm 2011;2:1531-3.

19. Mosmann T. Rapid colorimetric assay for cellular growth and survival: Application to proliferation and cytotoxicity assays. J Immunol Methods 1983;65(1-2):55-63. 
20. Denizot F, Lang R. Rapid colorimetric assay for cell growth and survival. Modifications to the tetrazolium dye procedure giving improved sensitivity and reliability. J Immunol Methods 1986;89(2):271-7.

21. Gillies RJ, Didier N, Denton M. Determination of cell number in monolayer cultures. Anal Biochem 1986;159(1):109-13.

22. Vidhya N, Devaraj SN. Induction of apoptosis by eugenol in human breast cancer cells. Indian J Exp Biol 2011;49(11):871-8.

23. Harborne JB. Phytochemical Methods. London: Chapman and Hall; 1973.

24. Dampier K, Hudson EA, Howells LM, Manson MM, Walker RA, Gescher A. Differences between human breast cell lines in susceptibility towards growth inhibition by genistein. Br J Cancer 2001;85(4):618-24.

25. Herlina T, Nurlelasari DK, Supratman U, Zalinar U. In vitro anticancer and antimalarial erystagallin a from Erythrina variegata (Leguminoseae) stem bark. Int J Phytomed Relat Ind 2001;1:9-13.

26. Elgadir AM, Salama M, Adam A. Anti-breast cancer from various natural sources-review. Int J Pharm Pharm Sci 2015;7:44-7.

27. Morse DL, Gray H, Payne CM, Gillies RJ. Docetaxel induces cell death through mitotic catastrophe in human breast cancer cells. Mol Cancer Ther 2005;4(10):1495-504.
28. Lowe SW, Lin AW. Apoptosis in cancer. Carcinogenesis 2000;21(8):485-95.

29. Heber D. Vegetables, fruits and phytoestrogens in the prevention of diseases. J Postgrad Med 2004;50(2):145-9.

30. Taraphdar AK, Roy M, Bhattacharya RK. Natural products as inducers of apoptosis: Implication for cancer therapy and prevention. Curr Sci 2001;80:1387-96

31. Haris M, Mahmood R, Rahman H, Rahman N. In vitro cytotoxic activity of Clerodendrum infortunatum L. Against T47D, PC-3, A549 and HCT-116 human cancer cell lines and its phytochemical screening. Int J Pharm Pharm Sci 2016;8:439-44.

32. Deschner EE, Ruperto J, Wong G, Newmark HL. Quercetin and rutin as inhibitors of azoxymethanol-induced colonic neoplasia. Carcinogenesis 1991;12(7):1193-6.

33. Ravindranath N, Ravinder Reddy M, Ramesh C, Ramu R, Prabhakar A, Jagadeesh B, et al. New lathyrane and podocarpane diterpenoids from Jatropha curcas. Chem Pharm Bull (Tokyo) 2004;52(5):608-11.

34. Furusawa S, Wu J, Fujimura T, Nakano S, Nemoto S, Takayanagi M, et al. Cepharanthine inhibits proliferation of cancer cells by inducing apoptosis. Methods Find Exp Clin Pharmacol 1998;20(2):87-97. 